UDC 811.111`373`38`42:311.9

DOI https://doi.org/10.32841/2409-1154.2020.46-1.16

\author{
Vilkhovchenko N.P., \\ Ph. D. in Philology, Associate Professor, \\ Associate Professor at the Department of Foreign Languages \\ Lviv Polytechnic National University
}

\author{
Shayner H. I., \\ Ph. D. in Pedagogy, Associate Professor, \\ Associate Professor at the Department of Foreign Languages \\ Lviv Polytechnic National University
}

\title{
INTERACTION OF TERMS AND QUASI-SPECIAL VOCABULARY IN SCIENCE FICTION TEXTS
}

Summary. The article focuses on the definition of the concept of quasi-special vocabulary. It determines the role of this lexical layer in creating the atmosphere of future, exoticism, and fantasy. The paper is also devoted to the analysis of the interaction of the two lexical layers, such as quasi-special vocabulary (i.e. special vocabulary coined by the author) and the terms that exist. Quasi-special units in a science fiction text are considered as fantastisms. They are compared to the extotisms which exist in language. Similar to them, quasi-special vocabulary is also able to acquire a stylistic colouring in the text. On the one hand, this vocabulary is perceived as familiar, neutral for the characters of the imaginary world. On the other hand, it is unknown and exotic to the reader. The research proves that units of special vocabulary are able to manifest exotic colouring most intensely when they correlate with the thematic groups of the exoticisms that exist in language. Such groups include the author's astronyms, toponyms, oronyms, hydronyms which are "familiar" to future civilizations, as well as the names of professions, institutions, the names of representatives of flora and fauna, units of measurement, etc. Our research shows that interaction of terminology and quasi-terms, coined by the author, is a unique feature of the lexical design of science fiction texts. Interacting, they are able to create a linguistic picture of the author's imaginary world. Both terms and quasi-special vocabulary are a part of a common terminological system that belongs to a particular scientific field. The results of the study show that quasi-special vocabulary is in some way "embedded" in the general terminological system and does not create its own. Thus, units of quasi-special vocabulary that belong to a certain scientific field acquire a so-called "scientific" component of meaning. In addition, the interaction of quasi-special vocabulary and terminology occurs when the term gets imaginary semantic component. The paper concludes that the interaction of terms and quasi-special vocabulary creates a conceptual system which becomes the basis of a specific linguistic picture of the fantasy world.

Key words: quasi-special vocabulary, terminology, science fiction text, linguistic picture, the author's imaginary world.

Formulation of the problem. Characteristic features of science fiction (fantasy character, artistic imitation of science) outline the genre specificity; they determine the pragmatic features of the science fiction text. These features are defined by the combination of a number of elements, including fiction and science, setting both on fiction and illusion of authenticity [1].
Creating fantasy worlds, the author introduces imaginary realias (i.e. words that denote objects of the fantasy world). Therefore, the features of the fantasy world linguistic picture are determined by the interaction of special and quasi-special vocabulary. The latter is interpreted as a layer of lexical neologisms that denominates objects and phenomena existing exclusively in the author's fantasy world. Being genre-shaping, special vocabulary is the basis of the lexical system of science fiction texts [2].

The aim of the study is to define the concept of quasi-special vocabulary, to determine its role in creating the atmosphere of future, exoticism, and fantasy. The article considers the interaction of quasi-special vocabulary (i.e. special vocabulary coined by the author) and the terms that exist. The object of the research is quasi-special vocabulary (1097 units) and scientific terminology (1900 units). This vocabulary was selected by a continuous sample of English-language science fiction works, e.g. "Starship Titanic" by T. Jones [14], "The road to Mars" by E. Idle [13], "The songs of distant Earth" by A. Clark [9], "Steelheart" by W. Dietz [10], "Neuromancer" by W. Gibson [12] and others, with a total volume of about 3500 pages.

Review of recent research and publications on this issue. A number of Ukrainian and foreign scientists have made a significant contribution to the study of the peculiarities of the language design of science fiction works. It is necessary to distinguish such specialists as Stuzhuk A., Teslenko T., Kalynyuk A., Katysh T., Gibson R., Mandala S., Kirkham D.

Dzyubina O., Konopatska Ya., Kostyuk Y., Struganets L., Ahmad K., Aitchison J. devoted their papers to the detailed study of lexical innovations. Scientists considered various aspects of this lexical layer. For example, they paid attention to the impact of lexical innovations on the stability of the language system [8]. Other aspects include different types of word formation [5; 7], general problems of modern language lexical system development, including the processes of integration of neologisms into the language [4]. The works of researchers study the existing trends in the development of lexical and semantic systems in artistic texts [3]. In particular, the works outline the role of science fiction vocabulary in creating an atmosphere of the future and exoticism. They also describe the peculiarities of the interaction of both science fiction vocabulary and the terms that exist $[1 ; 2 ; 11]$.

Presenting main material. Quasi-special lexical units (i.e. the author's special vocabulary) are able to create the colouring 
of fantasy and exoticism in a science fiction text [2]. As a rule, the use of such vocabulary is associated with the realia of imaginary worlds. These realia include the description of extraterrestrial life, technological and scientific innovations that will exist in the future. So, quasi-special units in a science fiction text are considered as fantastisms (i.e., fantasy exoticisms).

Exoticisms are known to be the words borrowed from other languages that denote the realias of life of another country or people. Similar to such exotisms, quasi-special vocabulary also acquires a stylistic colouring in the text. On the one hand, this vocabulary is perceived as familiar, neutral for the characters of the imaginary world, and on the other hand, it is new, unknown, and exotic to the reader.

Most intense manifestation of the exotic colouring is observed in units of special vocabulary that correlate with the thematic groups of the exoticisms that exist in language. They include the author's astronyms, toponyms, oronyms, hydronyms which are "familiar" to future civilizations, as well as the names of professions, institutions and organizations, the names of representatives of flora and fauna, units of measurement. Here are examples of the use of some units of quasi-special vocabulary belonging to these thematic groups:

"The humans, who had been led to expect something verging on paradise, had arrived to find that Z Zul had been inhabited for hundreds of thousands of years" [10, p. 5].

"Mount Purlow had been the first to explode" [10, p. 4].

"A gbaanyi was about one and a half years, by Standard time, which was how these humans measured their days" [17, p. 176].

"Even the curtains in the crew rooms were woven from the hair of the silky canadil, which lives high up in the Mountains of Merlor" [14, p. 148].

These examples demonstrate the use of vocabulary which belongs to different thematic groups. It is able to create an exotic colouring in the works: Zuul (fictional astronym), Mount Purlow, Mountains of Merlor (alien oronyms), gbaanyi (unit of alien time), silky canadil (a representative of the alien fauna). These groups of vocabulary correlate with the thematic groups of the exoticisms that exist. This means that quasi-special vocabulary is determined by the thematic categories of exoticisms. We can compare this with depicting the realias of past epochs when outdated vocabulary (archaisms) is used as a figurative means in the artistic text. By analogy, when describing the future, the fantastisms of the future demonstrate similar stylistic function:

"She, Captain Becker, RK, and Aari had stood on the lowered platform of the robolift' [17, p. 14].

In this passage, the word "robolift" is a fantastism that denotes a robotic elevator. This object "exists" only in the author's imaginary world. This word is able to create an atmosphere of the future because the world, where this object exists, is in the imaginary future.

Our research shows that interaction of terminology and quasi-terms, coined by the author, is a unique feature of the lexical design of science fiction texts. Interacting, they are able to create a linguistic picture of the author's imaginary world. The latter is defined as a reflection of both imaginary every day knowledge and scientific one presented in the symbolic form of natural language. It covers notions invented by the author, as well as those that do exist and reflect imaginary knowledge of characters about their world. In particular, the linguistic picture of the fantasy world is based on a conceptual system that includes both terminology that exists and quasi-special vocabulary. Their functioning in science fiction is based on interaction.

It is noteworthy that in a science fiction text, both terms and quasi-special vocabulary are part of a common terminological system, belonging to a particular scientific field. The results of the study show that quasi-special vocabulary is in some way "embedded" in the general terminological system and does not create its own. Thus, units of quasi-special vocabulary that belong to a certain scientific field acquire a "scientific" component of meaning. On the other hand, the interaction of quasi-special vocabulary and terminology also occurs when the term acquires imaginary semantic component.

Another feature of the interaction of units of special vocabulary in science fiction text is that the author describes unknown, imaginary phenomena. And such a description is based on familiar facts with the use of the terms that exist. The following example helps to analyze the interaction of the quasi-special vocabulary and terms:

"Their attention was immediately focused on "the Princess Diana", a monstrously large solar cruiser, the flagship of the Keppler fleet. It was the most gigantic cruise ship they had ever seen" [14, p. 20].

In this example, the author uses both terms (flagship, cruise ship) and quasi-special vocabulary (Keppler fleet, solar cruiser, "the Princess Diana"). Here, we can trace the interaction of the quasi special vocabulary with the terms that exist. In particular, the collocation "solar cruiser" consists of two terms that acquire fantasy meaning in the phrase which is a hyperonym for the unit "the Princess Diana". The term "fleet" is used in the phrase "Keppler fleet". The word "Keppler" denotes belonging to another civilization, so "fleet" acquires a new fantasy meaning. "Flagship" is a term, but when interacting with the quasi-terms "Keppler fleet" and "solar cruiser" it also acquires a new semantic component "flagship of the alien fleet". And finally, the "cruise ship" gets a fantasy semantic component because in this example it becomes a synonym of the quasi-term "solar cruiser".

Here is another example of the interaction of quasi-special vocabulary and terms:

"From the Central Well of the Starship ran two great canals - one to the fore and one to the aft. These partly had the effect of cooling the engines, but they were also elegant recreational facilities" [14, p. 23].

We can observe the interaction of quasi-special vocabulary ("Central Well, Starship") with the terms ("fore, aft, engines"). Interacting with the quasi-special unit "Starship", the terms "fore, aft and engines" acquire a fantasy semantic component of "spaceship stern and spacecraft engines".

The following example also illustrates the interaction:

"There was the famous house he designed for Gardis Arbledonter, the Professor of Mathematical Implausibilities at Blerontis University, in which the doors were actually radio sets ..." [14, p. 31].

In the given example, the author uses quasi-special collocation "Professor of Mathematical Implausibilities" and "Blerontis University". These phrases consist of special vocabulary (Professor, Mathematical, and University). In the first phrase, the interaction of the terms which normally are not combined in language is able to fill the phrase with the fantasy and exotic meaning. The second phrase consists of the quasi-special unit "Blerontis" (i.e. belonging to an alien civilization) and the word "University". In addition, the combination of these words concentrates a fantastic atmosphere 
because the scientific degree of an imaginary science at the university on an imaginary planet is mentioned. Therefore, the analysis of special vocabulary in science fiction allows us to conclude that the interaction of terms and quasi-special vocabulary creates a conceptual system, which is the basis of a specific linguistic picture of the fantasy world.

Conclusions and prospects of the study. Functioning in the science fiction text, quasi-special vocabulary is able to create an exotic and fantasy colouring. Coexistence and interaction of these lexical layers in the text, creates a linguistic picture of the fantasy world. The quantitative predominance of the terms is due to the fact that the author tries to describe the unknown imaginary objects and phenomena with the reference to the familiar ones, so he/she uses the terminology that exists. In fact, special and quasi-special vocabulary belong to the common terminological system of the science fiction world, in which quasi-special vocabulary is part of the existing general terminological system and does not create its own. In the future, we are planning to research features of the word formation by various English-speaking authors in order to follow modern trends in creation of the fantasy world language system.

\section{References:}

1. Вільховченко Н., Колесник Г. Особливості функціонального підходу до дослідження науково-фантастичного тексту. Наукові записки Національного університету «Острозька академія»: Серія «Філологія». 2019. Вип. 2(70). С. 45-47.

2. Вільховченко Н.П., Шайнер А.І. Фантастизми та терміни в науково-фантастичному тексті: принципи взаємодії. Науковий вісник Міжнародного гуманітарного університету: Серія «Філологія». 2019. № 43. Том 2. С. 74-76. DOI https://doi.org/10.32841/2409-11 54.2019.43.2.19

3. Дзюбіна О.І. Диференціальні ознаки неологізмів і оказіоналізмів (на матеріалі художньої літератури та Інтернет-реклами англійської мови). Вісник ЛНУ ім. I. Франка. Сер.: іноземні мови. 2014. № 22. C. 78-84.

4. Конопацька Я. Особливості інтеграції нових лексичних одиниць у систему мови. Вісник Львів. ун-ту. Серія іноземні мови. 2012. Вип. 19. С. 174-179.

5. Костюк Ю. Афіксальне словотворення суспільно-політичної неолексики. Лінгвостилістичні студіï. 2017. С. 78-84.

6. Струганець Л.В. Динаміка лексичних норм української літературної мови XX століття. Тернопіль : Астон, 2002. 352 с.

7. Ahmad K. Neologisms, Nonces and Word Formation. The 9th EURALEX Int. Congress (8-12 August 2000, Munich). Vol. II. Munich: Universitat Stuttgart. P. 711-730.

8. Aitchison J. Language Change: Decay or Evolution. Cambridge, 1991. $240 \mathrm{p}$.

9. Clarke A. The Songs of Distant Earth. London, 2001. 242 p.

10. Dietz W. Steelheart. New York, 1998. 324 p.

11. Gibson R. Inventors of Words - Neologisms in science fiction. URL: https://ezinearticles.com/?Inventors-of-Words---Neologisms-inScience-Fiction\&id=842869 (accessed 20.01.2021).

12. Gibson W. Neuromancer. New York, 1984. 271 p.
13. Idle E. The Road to Mars. London, 1999. 309 p.

14. Jones T. Starship Titanic. New York, 1998. 246 p.

15. Kirkham D. Encountering conlangs. Babel. The Language Magazine. № 18. February 2017. P. 10-15.

16. Mandala S. The Language in Science Fiction and Fantasy. NY, 2012. $246 \mathrm{p}$.

17. McCaffrey E., Scarborough A. Acorna`s World. New York, 2000. $306 \mathrm{p}$.

18. Nordquist R. How Neologisms Keep English Alive. ThoughtCo. URL: https://www.thoughtco.com/neologism-words-term-1691426 (accessed 25.01. 2021).

Вільховченко Н.П., Шайнер Г.І. Взасмодія термінів і квазіспеціальної лексики в науково-фантастичному тексті

Анотація. Статтю присвячено визначенню поняття квазіспеціальної лексики. Визначено роль цього лексичного шару у створенні атмосфери майбутнього, екзотичності та фантастичності. У статті також здійснено аналіз взаємодії двох лексичних шарів, а саме: квазіспеціальної лексики (тобто спеціальної лексики, вигаданої автором) та термінів, що існують. Квазіспеціальні одиниці в науково-фантастичному тексті розглядають як фантастизми. Їх порівнюють з екзотизмами, які існують у мові. Подібно до них, квазіспеціальна лексика також здатна набувати стилістичного забарвлення в тексті. 3 одного боку, цю лексику сприймають як звичну, нейтральну для персонажів уявного світу. 3 іншого боку, вона $є$ невідомою і екзотичною для читача. Дослідження доводить, що одиниці спеціальної лексики здатні проявляти екзотичне забарвлення найбільш інтенсивно, коли вони співвідносяться з тематичними групами екзотизмів, що існують у мові. До таких груп належать авторські астроніми, топоніми, ороніми, гідроніми, які $є$ ніби «звичними» для майбутніх цивілізацій. До цієї групи також зараховують назви професій, установ, представників флори та фауни, одиниці виміру тощо. Наше дослідження показує, що взаємодія термінології та квазітермінів, створених автором, $\epsilon$ унікальною особливістю лексичного оформлення науково-фантастичних текстів. Взаємодіючи, вони здатні створити лінгвістичну картину уявного світу автора. Як терміни, так і квазіспеціальна лексика є частиною загальної термінологічної системи, яка належить до певної наукової галузі. Результати дослідження показують, що квазіспеціальна лексика певним чином «вбудована» в загальну термінологічну систему і не створює своєї. Таким чином, одиниці квазіспеціальної лексики, що належать до певної наукової галузі, набувають так званої «наукової» складової частини значення. Крім того, взаємодія квазіспеціальної лексики та термінології проявляється тоді, коли термін набуває уявної семантичної складової частини. У результаті дослідження ми дійшли висновку, що взаємодія термінів та квазіспеціальної лексики створює концептуальну систему, яка стає основою мовної картини світу науково-фантастичного тексту.

Ключові слова: квазіспеціальна лексика, термінологія, науково-фантастичний текст, лінгвістична картина, фантастичний світ автора. 